\title{
Binding of Retinoids to Human Breast Cancer Cell Lines and their Effects on Cell Growth
}

\author{
ANDre LaCroix and MarC E. Lippman, Medicine Branch, Division of Cancer \\ Treatment, National Cancer Institute, National Institutes of Health, \\ Bethesda, Maryland 20205
}

\begin{abstract}
A B S T R A C T Vitamin A and its analogues (retinoids) regulate the differentiation of epithelial tissues. Retinoids inhibit the induction of rat mammary cancers by carcinogens in vivo, and cellular binding proteins for retinoids have been demonstrated in some human breast cancer samples. In this study, we examined the model system of human breast cancer cell lines in long-term tissue culture for effects of retinoids on growth and for the presence of cellular retinoid binding proteins. Retinoic acid and retinol inhibit the growth of of MCF-7, Hs578T, and ZR-75-B cell lines. Retinoic acid is more potent than retinol in this regard: $50 \%$ growth inhibition is achieved by $6 \mathrm{nM}$ retinoic acid in ZR-75-B and by $700 \mathrm{nM}$ in MCF-7 and Hs578T, whereas $5-8 \mu \mathrm{M}$ retinol is required in all three cell lines. The time to onset of growth inhibition varies markedly between cell lines and is not related to.cell density or doubling time. Retinoic acid increases the doubling time of MCF-7 and ZR-75-B by two- to threefold, but causes cell death in Hs578T. The growth inhibition is reversible in every cell line by removal of retinoic acid. Specific and distinct binding of $\left[{ }^{3} \mathrm{H}\right]$ retinoic acid and $\left[{ }^{3} \mathrm{H}\right]$ retinol is present in cytosols of MCF-7 and Hs578T cells as assessed by sucrose density gradient centrifugation. In ZR-75-B, $\left[{ }^{3} \mathrm{H}\right]$ retinoic acid binding was present, but no binding of $\left[{ }^{3} \mathrm{H}\right]$ retinol was detectable. This study reveals that retinoids may play an important role in the regulation and treatment of human breast cancer and that human breast cancer cell lines represent a useful model to study this role.
\end{abstract}

\section{INTRODUCTION}

Retinol (vitamin A) plays an important role in the maintenance of normal growth and in the differentiation of

This work was presented in part at the 61st Annual Meeting of The Endocrine Society, June 1979, Anaheim, Calif.

Dr. Lacroix was a recipient of a Centennial Fellowship from the Medical Research Council of Canada.

Received for publication 6 September 1979 and in revised form 22 October 1979. epithelial tissues (1). Retinol, retinoic acid, and their analogues (retinoids) have been shown to inhibit the chemical induction of epithelial tumors in vivo, to alter the expression of transformed cells in vitro, and to inhibit the growth of several cell lines $(2,3)$. Furthermore, retinoids can induce the differentiation of embryonal carcinoma cell lines (4). Recent studies have examined possible interactions between retinoids and breast cancer. Several retinoids have been shown to inhibit rat mammary carcinogenesis induced by 7,12 dimethylbenz(a)anthracene and by $N$-methyl- $N$-nitrosourea (4-7), and to decrease the initial tumor growth rate of a transplantable mammary adenocarcinoma in mice (8). Lotan and Nicolson reported growth inhibitory effects of retinoic acid and retinyl acetate in vitro on several rat, murine, and human mammary cancer cell lines $(9,10)$. Ong et al. (11) first reported the presence of a cytoplasmic retinoic acid binding protein in a small number of human breast cancer samples and, in a recent observation, Huber et al. (12) found that 15 of 29 primary human breast cancer samples examined had measurable amounts of the same cytoplasmic-binding protein.

The in vitro model system of human breast cancer cell lines in long-term tissue culture has proven useful in the study of the receptors and the effects of various hormones on cell growth (13). We now provide new information that cytoplasmic-binding proteins for retinoids are present in three human breast cancer cell lines, and we expand further on the growth regulatory effects of retinoids on these cell lines.

\section{METHODS}

Cells and tissue culture. The Hs578T cell line (14) was a generous gift from Dr. A. J. Hackett, Naval Biomedical Research Laboratory, Oakland, Calif. The ZR-75-B cell line is a cloned line derived in this laboratory from the ZR-75-1 cell line (15), and it possesses the same hormone receptors and hormonal responsiveness as the parent cell line. The MCF-7 cell line (16) was obtained from Dr. Marvin Rich, Michigan Cancer Foundation (Detroit, Mich.). All cell lines were maintained in monolayer culture in improved minimal essential medium. (National Institutes of Health Media Unit, Bethesda, Md.), sup- 
plemented with glutamine $(0.6 \mathrm{~g} /$ liter $)$, penicillin $(62 \mu \mathrm{g} / \mathrm{ml})$, streptomycin $(130 \mu \mathrm{g} / \mathrm{ml}$ ), and $10 \%$ fetal calf serum (Grand Island Biological Co., Grand Island, N. Y.). Cells were grown in a humidified incubator in $5 \% \mathrm{CO}_{2}$ at $37^{\circ} \mathrm{C}$. The cells were refed with media twice weekly and subcultured weekly with the use of $0.05 \%$ trypsin- $0.02 \%$ EDTA in $150 \mathrm{mM} \mathrm{NaCl}$ to remove the cells from the culture dishes.

Effects of retinoids on cell growth. To examine the effects of retinoids on cell growth, cells were plated in six well dishes (Costar, Data Packaging, Cambridge, Mass.) at a density such that confluency would be reached within 8-10 d in the previously described media supplemented with 10 (MCF-7 and ZR-75-B) or 2.5\% (Hs578T) fetal calf serum. On the following day (day 0), the media was changed and retinoids were added, and this procedure was repeated on days 3 and 6 . All-trans retinol and all-trans retinoic acid (Sigma Chemical Co., St. Louis, Mo.) were diluted to $10 \mathrm{mM}$ in ethanol, and stored at $-20^{\circ} \mathrm{C}$. Retinoids were serially diluted in ethanol to concentrations ranging from $10 \mathrm{mM}$ to $100 \mathrm{nM}$ immediately before adding directly to triplicate wells in a 1,000-fold dilution to yield final concentrations in the media ranging from $10 \mu \mathrm{M}$ to $0.1 \mathrm{nM}$. Ethanol did not exceed $0.1 \%$, and also was added to the control wells. All operations with retinoids were performed under subdued light. After $7 \mathrm{~d}$ of treatment, the cells were harvested with $0.01 \%$ trypsin- $0.02 \%$ EDTA in saline, and cell numbers were determined using an electronic particle counter model B (Coulter Electronics Inc., Hialeah, Fla.). To study the time-course of retinoid effects, cells were plated as described previously in six well dishes; on the following day, either $0.1 \%$ ethanol or retinoic acid was added to triplicate wells to yield the final concentrations indicated. The cells were refed with media and retinoic acid every $3 d$, and dishes were harvested daily for cell counts.

Measurement of cytoplasmic binding of retinoids. Cells grown in monolayer were washed with phosphate-buffered saline and scraped from the bottom of the flasks with a rubber policeman as they just reached confluency. The cells were then pelleted by centrifugation at $400 \mathrm{~g}$, washed once in phosphate-buffered saline, and stored at $-20^{\circ} \mathrm{C}$ until assay. The cells were homogenized in $50 \mathrm{mM}$ Tris- $\mathrm{HCl}$ buffer, $\mathrm{pH} 7.5$, using a glass Dounce homogenizer. The homogenate was centrifuged at $110,000 \mathrm{~g}$ for $60 \mathrm{~min}$, and the supernatant cytosol was used in the incubation with a protein concentration (17) between 8 and $14 \mathrm{mg} / \mathrm{ml}$. Cytosols were incubated with either $2.3 \mathrm{nM}\left[11-12-{ }^{3} \mathrm{H}\right] \mathrm{retinoic}$ acid $(36.6 \mathrm{Ci} / \mathrm{mmol}$; Hoffmann-LaRoche, Nutley, N. J.) or with $280 \mathrm{nM}\left[1-{ }^{3} \mathrm{H}\right]$ retinol (1.23 Ci/mmol; New England Nuclear, Boston, Mass.). In parallel incubations unlabeled retinoic acid or retinol in a 200fold molar excess was added with the radiolabeled retinoids. All operations were performed at $4^{\circ} \mathrm{C}$ in subdued light. The samples were incubated for $4 \mathrm{~h}$ after which an aliquot was mixed with the pellet from an equal volume of $\mathrm{T} 70$ dextran $(0.025 \%)$-coated charcoal $(2.5 \%)$, incubated for $10 \mathrm{~min}$, and centrifuged at $2,250 \mathrm{~g}$ for $10 \mathrm{~min}$ to remove the unbound ligand (11). $250 \mu \mathrm{l}$ of the supernate were then applied on top of a $5-20 \%$ sucrose density gradient in $10 \mathrm{mM}$ Tris- $\mathrm{HCl}$, pH 7.5 buffer containing $1 \mathrm{mM}$ disodium EDTA, $10 \mathrm{mM}$ $\mathrm{KCl}$, and $10 \mathrm{mM}$ monothioglycerol. $\left[{ }^{14} \mathrm{C}\right]$ bovine serum albumin $(4.6 \mathrm{~S})$ or $\left[{ }^{14} \mathrm{C}\right]$ cytochrome $c$ (1.71S; New England Nuclear) was added to each tube as a molecular weight marker. The sucrose density gradients were then centrifuged at $243,000 \mathrm{~g}$ for $16 \mathrm{~h}$ at $4^{\circ} \mathrm{C}$. Fractions of 125 or $250 \mu \mathrm{l}$ were collected by piercing the bottom of the tube and were counted for tritium and carbon-14 in a liquid scintillation spectrophotometer (Packard Tri Carb, model 3390; Packard Instrument Co. Inc., Downers Grove, Ill.). Corrections were made for crossover between channels, and results are expressed as disintegrations per minute of $\left[{ }^{3} \mathrm{H}\right]$ retinoid per fraction.

\section{RESULTS}

Effects of retinoids on the grouth of human breast cancer cell lines. The addition of retinoids to the cells in culture results in growth inhibition. Each cell line responds differently however in its dose-response and time-course curves.

The dose-response curves (Fig. 1) demonstrate that $50 \%$ growth inhibition by retinoic acid is achieved at $6 \mathrm{nM}$ in ZR-75-B and at $700 \mathrm{nM}$ in MCF-7 and Hs578T. Retinol is less potent than retinoic acid in its growth inhibitory effect, and $50 \%$ growth inhibition is achieved at $5-8 \mu \mathrm{M}$ retinol.

Striking differences in the time of onset and in the pattern of growth inhibition by retinoic acid exist between the three cell lines (Fig. 2). In MCF-7, growth inhibition is not evident before the 5th $\mathrm{d}$ of treatment with $1 \mu \mathrm{M}$ retinoic acid. After this initial delay period, the treated cells continue to grow and eventually reach a density similar to the control cells, but the doubling time is increased from 24 to $60 \mathrm{~h}$. In this particular experiment with MCF-7 cells, the retinoic acid was added at the time of plating, and no effect is noted on the plating efficiency. In Hs578T, treatment with $1 \mu \mathrm{M}$ retinoic acid results in an initial slowing in growth rate: the cell number is lower in treated than in control

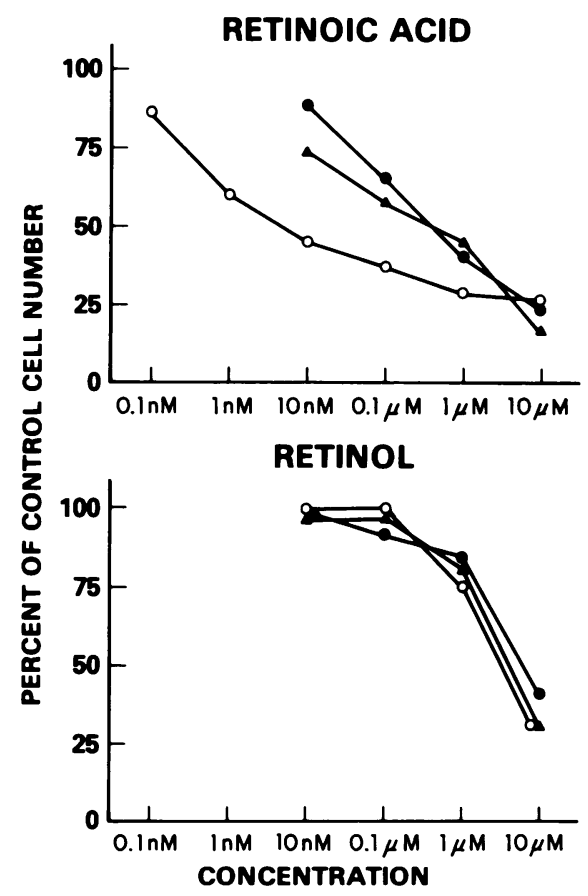

Figure 1 Dose-response curve of growth inhibition of MCF-7 ( ), Hs578T $(\Delta)$, and ZR-75-B (O) cell lines after $7 \mathrm{~d}$ of treatment with retinoic acid (top panel) and retinol (bottom panel). The mean of triplicate wells cell numbers is expressed as a percentage of control cell number. The SD of the triplicate cell numbers did not exceed $10 \%$. 

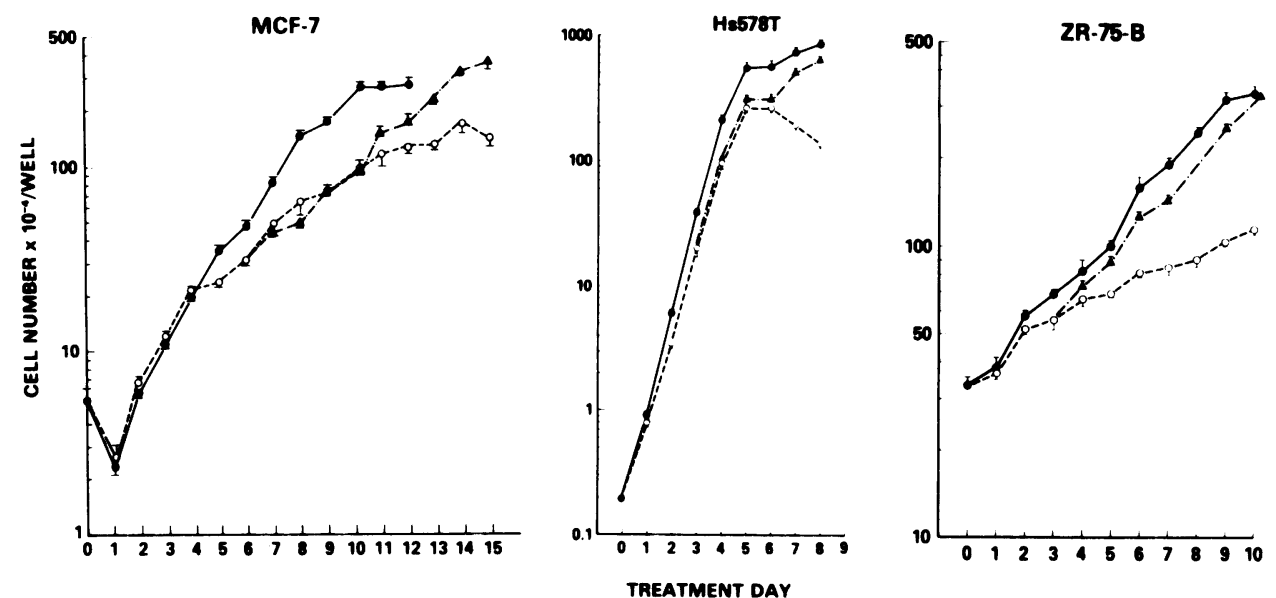

FIGURE 2 Time-course of growth inhibition of MCF-7, Hs578T, and ZR-75-B cell lines by retinoic acid. At day 0 , and every $3 \mathrm{~d}$ thereafter, the media were changed, and either ethanol $(\boldsymbol{O}$, control) or retinoic acid $(O)$ was added at a final concentration of $1 \mu \mathrm{M}$ (MCF-7 and Hs578T) or $10 \mathrm{nM}(\mathrm{ZR}-75-\mathrm{B})$. For the washout of retinoic acid $(\boldsymbol{\Delta})$, the media were removed from retinoic acid-treated cells after $6 \mathrm{~d}$ in MCF-7 or $3 \mathrm{~d}$ in Hs578T and ZR-75-B; the wells were rinsed twice with fresh media, and ethanol was added to the media. Cells from triplicate wells were harvested daily and counted. Results are shown as the mean of cell numbers \pm SD.

dishes by $15 \%$ after $24 \mathrm{~h}$ and by $42 \%$ after $48 \mathrm{~h}$. The total cell number increases until the 6 th $\mathrm{d}$ of treatment when the appearance of detached and dead cells is reflected by a decline in total cell number. The timecourse of the ZR-75-B growth inhibition was done with $10 \mathrm{nM}$ retinoic acid, a concentration which produces a degree of growth inhibition similar to $1 \mu \mathrm{M}$ in MCF-7 and Hs578T cell lines. In ZR-75-B, a considerable decrease in growth rate begins by the $2 \mathrm{nd} d$ of treatment with retinoic acid, and the doubling time increases from 60 to $144 \mathrm{~h}$. After $10 \mathrm{~d}$ of treatment in ZR-75-B, no evidence of cell loss similar to that noted in Hs578T was present.

In all three breast cancer cell lines, retinoic acid was washed out at a time when growth inhibition was clearly present (Fig. 2). This results in the restoration of a normal growth rate and achievement of a final cell number similar in control and in retinoic acid washed wells. However, the time required to restore a normal growth rate is different in each cell line: $5 \mathrm{~d}$ after washout in MCF-7, $4 \mathrm{~d}$ after washout in Hs578T, and $1 \mathrm{~d}$ after washout in ZR-75-B.

To assess whether the delay in onset of MCF-7 growth inhibition is related to the time required to reach a specific cell density where inhibition of growth is initiated, MCF-7 cells were plated at three different densities (Fig. 3). Irrespective of cell density, the decrease in growth rate caused by $1 \mu \mathrm{M}$ retinoic acid is delayed for $4-5 \mathrm{~d}$.

Cytoplasmic binding of retinoids to human breast cancer cell lines. The incubation of $\left[{ }^{3} \mathrm{H}\right]$ retinoic acid with the cytosol prepared from either one of the three breast cancer cell lines results in a peak of binding which migrates in the $2 S$ region of the sucrose density gradients (Fig. 4, panel A). This binding is decreased by the addition of a 200 -fold molar excess of unlabeled

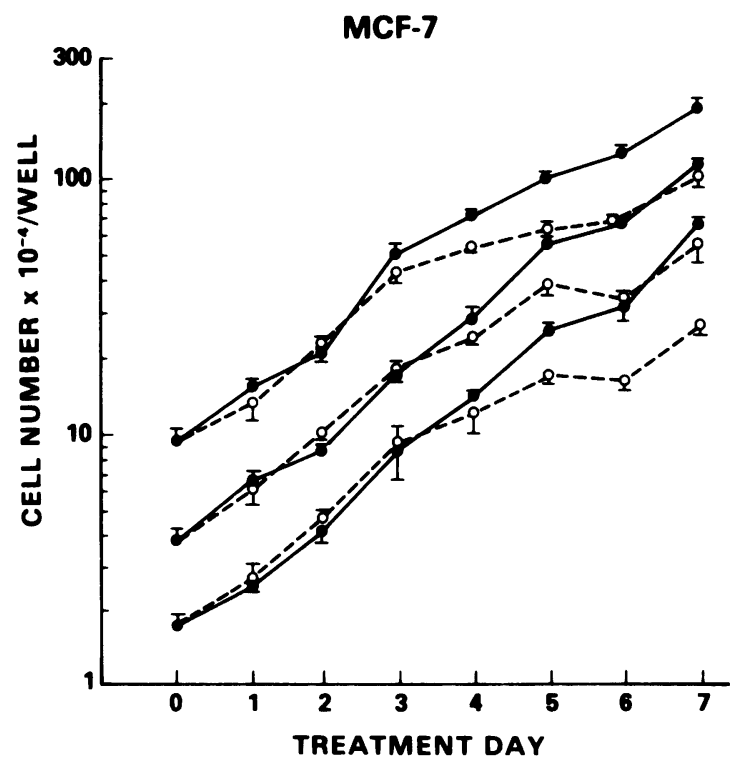

FIGURE 3 Effects of cell density on the onset of MCF-7 growth inhibition by retinoic acid. MCF-7 cells were plated at three different densities. On the following day (day 0), and every $3 \mathrm{~d}$ thereafter, cells were refed with media and either ethanol alone $(\Theta$, control) or with $1 \mu \mathrm{M}$ retinoic acid $(\bigcirc)$. Dishes were harvested daily, and cells were counted. Results are shown as the mean of triplicate wells cell number $\pm S D$. 

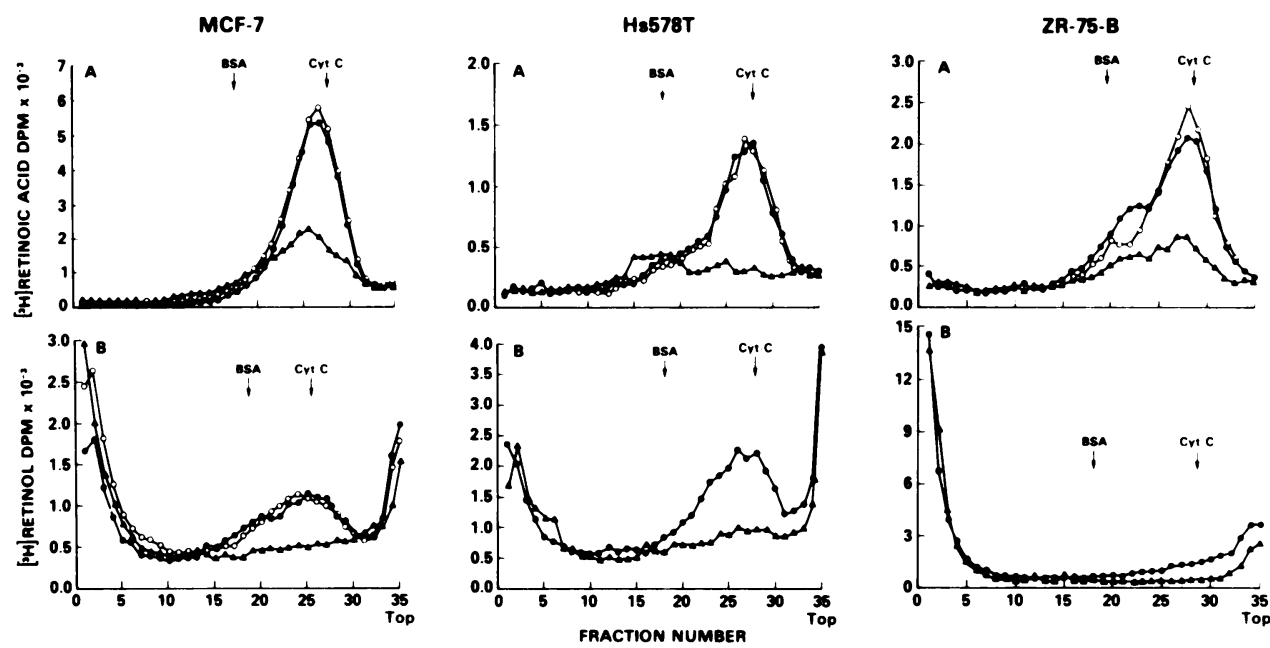

Figure 4 Sucrose-density gradient analysis of binding of $\left[{ }^{3} \mathrm{H}\right]$ retinoic acid and $\left[{ }^{3} \mathrm{H}\right] \mathrm{retinol}$ to cytosols of MCF-7, Hs578T, and ZR-75-B cells. Panel A, cytosols were incubated with $2.3 \mathrm{nM}$ $\left[{ }^{3} \mathrm{H}\right.$ ]retinoic acid either alone $(\bullet)$ or with the addition of 200 -fold molar excess of nonradiolabeled retinoic acid $(\mathbf{\Delta})$ or retinol $(O)$; panel $\mathbf{B}$, cytosols were incubated with $280 \mathrm{nM}\left[{ }^{3} \mathrm{H}\right]$ retinol either alone $(O)$ or with the addition of 200 -fold molar excess on nonradiolabeled retinol $(\boldsymbol{A})$ or retinoic acid $(O)$. The respective migration peaks of bovine serum albumin (BSA) (4.6S) and cytochrome-c (Cyt-C) (1.71S) are indicated by arrows.

retinoic acid but not by the addition of 200 -fold molar excess of retinol. No binding is present when $\left[{ }^{3} \mathrm{H}\right]$ retinoic acid is incubated with improved minimal essential medium, whereas incubation with improved minimal essential medium plus $10 \%$ fetal calf serum results in a peak of binding in the $4.6 \mathrm{~S}$ region which is not competed by the addition of 200 -fold molar excess of unlabelled retinoic acid (not shown).

The binding of $\left[{ }^{3} \mathrm{H}\right]$ retinol to the cytosols of the three cell lines is shown in Fig. 4 (panel B). A peak of binding of $\left[{ }^{3} \mathrm{H}\right]$ retinol which also migrated in the $2 \mathrm{~S}$ region of the sucrose density gradients is present in MCF-7 and Hs578T. This binding is decreased by the addition of a 200 -fold molar excess of unlabeled retinol but not by a 200 -fold molar excess of retinoic acid. No specific binding of $\left[{ }^{3} \mathrm{H}\right]$ retinol is detectable in the cytosol of ZR-75-B cells in three separate experiments even when incubated with $1 \mu \mathrm{M}\left[{ }^{3} \mathrm{H}\right]$ retinol (not shown). A substantial number of counts are present in the bottom fractions of samples incubated with $\left[{ }^{3} \mathrm{H}\right] \mathrm{retinol}$ but they are not competed by the addition of unlabeled retinol or retinoic acid.

\section{DISCUSSION}

Our results demonstrate that retinoids exert profound effects on the growth of MCF-7, Hs578T, and ZR-75-B human breast cancer cell lines. We also demonstrate the presence of binding proteins for retinoids in human breast cancer cell lines in long-term tissue culture.

The three breast cancer cell lines examined exhibit striking differences in the pattern of growth inhibi- tion by retinoids. A 2.4-fold increase in doubling time is achieved by treatment with $1 \mu \mathrm{M}$ retinoic acid in MCF-7 but by only $10 \mathrm{nM}$ retinoic acid in ZR-75-B. This last cell line's growth is inhibited by concentrations of retinoic acid as low as $0.1 \mathrm{nM}$. The time of onset of growth inhibition varies quite remarkably between the cell lines. In addition, retinoic acid affected the viability of the Hs578T cells but not of the MCF-7 or ZR-75-B cells at the concentrations and time schedules examined. Our observations are in accordance with Lotan's results in four human breast cancer cell lines as well as in many other cell types $(9,10)$. It is of interest that the dose-response and the time-course findings on the growth inhibition of MCF-7 cells are very similar to those in the 734B cell line (10) from which the MCF-7 cell line originated (15). It is apparent, however, that in our experience the effects of retinoids on the Hs578T cell line are more marked than previously reported $(9,10)$. Inasmuch as retinoic acid binds to serum, probably to albumin (18), it is possible that the lower concentrations of fetal calf serum in our media $(2.5 \%$ vs. $10 \%)$ modify the bioavailability of the retinoic acid and explain the differences in the growth inhibition. Selection of a subline which would now be more sensitive to retinoids is also a possibility.

It does not appear that the rate of cell proliferation alone can explain the differences in the time to onset of growth inhibition: it occurs earlier in the ZR-75-B than in the MCF-7 cell line ( 2 vs. $5 \mathrm{~d}$ ) despite a slower doubling time in the former than in the latter $(60 \mathrm{vs} .24 \mathrm{~h}$ ).

Retinoids can restore density-dependent inhibition of growth as shown in L-cell proliferation (19). We 
thus examined whether the delay in onset of growth inhibition in MCF-7 could be explained by the time required to reach a cell density at which contact inhibition was induced. Our data in MCF-7 cells do not support the possibility that the growth inhibition is density dependent. The MCF-7 cells treated with retinoic acid eventually reach a high cell density as the untreated cells (Fig. 2), and the cell density does not modify the time to onset of growth inhibition.

The following facts suggest that the effects of retinoids on cell proliferation are not nonspecific toxic effects: $(a)$ growth inhibition is present at concentrations of retinoids not associated with toxicity as measured in tracheal organ cultures (20); (b) MCF-7 cells continue to grow slowly despite prolonged exposure to $1 \mu \mathrm{M}$ retinoic acid; $(c)$ reversal of growth inhibition follows the removal of retinoic acid; $(d)$ concentrations of retinoic acid up to $10 \mu \mathrm{M}$ had no effect on the growth or survival of the MDA-MB-157 human breast cancer cell line, or the Hs578BsT and HBL-100 normal human breast lines (10). The physiological significance of these data is unclear because retinoic acid is not detectable in the peripheral circulation. Normal blood levels of retinol in man range between 1.1 and 2.3 $\mu \mathrm{M}(21)$, and $50 \%$ growth inhibition follows treatment with 5-8 $\mu \mathrm{M}$ retinol in the cell lines studied. It should be remembered however that, in vivo, retinol circulates tightly bound to retinol-binding protein and that comparisons with in vitro systems may not be valid.

The mechanism by which retinoids inhibit cell proliferation has not been elucidated. Our results as well as those of others in several different in vitro systems $(2,3)$ clearly show that retinoids exert at least part of their activity directly on the tumor cell. It is now well established that intracytoplasmic proteins which bind either retinoic acid or retinol are present in normal and tumoral tissues (22-27). We now provide new evidence that the same type of retinoic acid binding protein, as characterized by its $2 \mathrm{~S}$ mobility on sucrose density gradients and by its specificity, is present in the cytosol of MCF-7, Hs578T, and ZR-75-B cell lines. The serum component of retinoic acid binding migrates in the $4.6 \mathrm{~S}$ region where bovine serum albumin also migrates: this finding rules out the possibility that the binding detected in our cells is merely a contamination of the cytosol by the fetal calf serum in the tissue culture media. We can also detect the presence of specific cytoplasmic retinol-binding protein in two out of three cell lines examined. The presence of retinol binding protein has not been previously examined in human breast cancer samples but it was detected in a transplantable rat mammary carcinoma (27). It is interesting to note that the growth of ZR-75-B cells is inhibited by $10 \mu \mathrm{M}$ retinol and that no cytoplasmic retinol binding protein is detectable in this cell line. It should be ap- preciated that the detection of this binding protein is somewhat limited by the low specific activity of the ligand. It can be postulated that retinol could be oxidized to retinoic acid by these cells and that the growth inhibition is modulated by the retinoic acid binding protein. However, despite the generally good correlations in the binding and structure activity of retinoids $(26,28)$ and the demonstration of nuclear retinoid binding proteins $(24,26,29,30)$, no direct proof of a necessary role of the binding proteins in the antitumor activity of retinoids has been put forward. Furthermore, as our present data provide qualitative but not quantitative measurement of the binding proteins, no correlation between the sensitivity of the cell lines to growth inhibition by retinoids and the quantity or affinity of binding protein can be attempted at this time.

The presence of receptors for estrogens, progestogens, androgens, glucocorticoids, insulin, triiodothyronine, and their effect on cell growth of MCF-7 and ZR-75-1 cell lines has been recently reviewed (13). Although still controversial, the binding of prolactin to MCF-7 has also been reported recently (31), and additional roles in growth regulation could be played by epidermal growth factor (32), transferrin (33), and other growth factors. To this list, we can now add the presence of receptors for retinoids and growth inhibition by retinoids in human breast cancer lines in long-term tissue culture. These data suggest that retinoids could play an important role in the induction and conceivably in the treatment of human breast cancer. Finally, it is suggested that different human breast cancer cell lines with different phenotypic responses to retinoids could provide useful models to delineate further the mechanism of action of retinoids, the role played by the cellular retinoid binding proteins, and the possible interactions between retinoids and different hormones which regulate human breast cancer.

\section{ACKNOWLEDGMENTS}

The authors wish to thank Dr. W. E. Scott from HoffmanLaRoche for the generous gift of the $\left[{ }^{3} \mathrm{H}\right]$ retinoic acid; they are also grateful to Dr. B. Wiggert for her helpful suggestions.

\section{REFERENCES}

1. Wolbach, S. B., and P. R. Howe. 1925. Tissue changes following deprivation of fat-soluble A vitamin. J. Exp. Med. 42: 753-777.

2. Sporn, M. B., N. M. Dunlop, D. L. Newton, and J. M. Smith. 1976. Prevention of chemical carcinogenesis by vitamin $\mathrm{A}$ and its synthetic analogues (retinoids). Fed. Proc. 35: 1332-1338.

3. Sporn, M. B., and D. L. Newton. 1979. Chemoprevention of cancer with retinoids. Fed. Proc. 38: 2528-2534.

4. Strickland, S., and V. Mahdavi. 1978. The induction of differentiation in teratocarcinoma stem cells by retinoic acid. Cell. 15: 393-403.

5. Moon, R. C., C. J. Grubbs, and M. B. Sporn. 1976. In- 
hibition of 7, 12-dimethyl benz(a)anthracene-induced mammary carcinogenesis by retinyl acetate. Cancer Res. 36: 2626-2630.

6. Grubbs, C. J., R. C. Moon, M. B. Sporn, and D. L. Newton. 1977. Inhibition of mammary cancer by retinyl methyl ether. Cancer Res. 37: 599-602.

7. Moon, R. C., H. J. Thompson, P. J. Becci, C. J. Grubbs, R. J. Gander, D. L. Newton, J. M. Smith, S. L. Phillips, W. R. Henderson, L. T. Mullen, C. C. Brown, and M. B. Sporn. 1979. N-(4-hydroxyphenyl) Retinamide, a new retinoid for prevention of breast cancer in the rat. Cancer Res. 39: 1339-1346.

8. Rettura, G., A. Schittek, M. Hardy, S. M. Levenson, A. Demetriou, and E. Seifter. 1975. Antitumor action of vitamin $A$ in mice inoculated with adenocarcinoma cells. J. Natl. Cancer Inst. 54: 1489-1491.

9. Lotan, R., and G. L. Nicolson. 1977. Inhibitory effects of retinoic acid or retinyl acetate on the growth of untransformed, transformed, and tumor cells in vitro. J. Natl. Cancer Inst. 59: 1717-1722.

10. Lotan, R. 1979. Different susceptibilities of human melanoma and breast carcinoma cell lines to retinoic acid-induced growth inhibition. Cancer Res. 39: 10141019.

11. Ong, D. E., D. L. Page, and F. Chytil. 1975. Retinoic acid binding protein: occurrence in human tumors. Science (Wash. D. C.). 190: 60-61.

12. Huber, P. R., E. Geyer, W. Kung, A. Matter, J. Torhorst, and V. Eppenberger. 1978. Retinoic acid-binding protein in human breast cancer and dysplasia. J. Natl. Cancer Inst. 61: 1375-1378.

13. Osborne, C. K., and M. E. Lippman. 1978. Human breast cancer in tissue culture. The effects of hormones. In Breast Cancer Advances in Research Treatment. W. L. McGuire, editor. Plenum Publishing Corporation, New York. II: 103-154.

14. Hackett, A. J., H. S. Smith, E. L. Springer, R. B. Owens, W. A. Nelson-Rees, J. L. Riggs, and M. B. Gardner. 1977. Two syngeneic cell lines from human breast tissue: the aneuploid mammary epithelial (Hs578T) and the diploid myoepithelial (Hs578Bst) cell lines. J. Natl. Cancer Inst. 58: $1795-1800$.

15. Engel, L. W., N. A. Young, T. S. Tralka, M. E. Lippman, S. J. O'Brian, and M. J. Joyce. 1978. Establishment and characterization of three new continuous cell lines derived from human breast carcinomas. Cancer Res. 38: 33523364 .

16. Soule, H. D., J. Vazquez, A. Long, S. Abert, and M. Brennan. 1973. A human cell line from a pleural effusion derived from a breast carcinoma. J. Natl. Cancer Inst. 51: 1409-1413.

17. Lowry, O. H., N. J. Rosebrough, A. L. Farr and R. J. Randall. 1951. Protein measurement with the Folin phenol reagent. J. Biol. Chem. 193: 265-275.

18. Smith, J. E., P. O. Milch, Y. Muto, and D. S. Goodman.
1973. The plasma transport and metabolism of retinoic acid in the rat. Biochem. J. 132: 821-827.

19. Dion, L. D., J. E. Blalock, and G. E. Gifford. 1977. Vitamin A-induced density-dependent inhibition of L-cell proliferation. J. Natl. Cancer Inst. 58: 795-801.

20. Sporn, M. B., N. M. Dunlop, D. L. Newton, and W. R. Henderson. Relationships between structure and activity of retinoids. Nature (Lond.). 263: 110-113.

21. Roels, O. A. 1970. Vitamin A physiology. JAMA (J. Am. Med. Assoc.). 214: 1097-1102."

22. Chytil, F., and D. E. Ong. 1977. Cellular binding proteins for compounds with vitamin A activity. In Receptors and Hormone Action. B. W. O’Malley and L. Birnbaumer, editors. Academic Press, Inc., New York. II: 573-591.

23. Sani, B. P., and T. H. Corbett. 1977. Retinoic acidbinding protein in normal tissues and experimental tumors. Cancer Res. 37: 209-213.

24. Wiggert, B., P. Russell, M. Lewis, and G. Chader. 1977. Differential binding to soluble nuclear receptors and effects on cell viability of retinol and retinoic acid in cultured retinoblastoma cells. Biochem. Biophys. Res. Commun. 79: 218-225.

25. Saari, J. C., S. Futterman, G. W., Strubbs, J. T. Heffernan, L. Bredberg, K. Y. Chan, and D. M. Albert, 1978. Cellular retinol- and retinoic acid-binding proteins in transformed mammalian cells. Invest. Ophthalmol. Visual Sci. 17: 988-992.

26. Jetten, A. M., and M. E. R. Jetten. 1979. Possible role of retinoic acid binding protein in retinoid stimulation of embryonal carcinoma cell differentiation. Nature (Lond.). 278: 180-182.

27. Ong, D. E., and F. Chytil. 1976. Presence of cellular retinol and retinoic acid binding proteins in experimental tumors. Cancer Lett. 2: 25-30.

28. Chytil, F., and D. E. Ong. 1976. Mediation of retinoic acid-induced growth and anti-tumor activity. Nature (Lond.). 260: 49-51.

29. Takase, S., D. E. Ong, and F. Chytil. 1979. Cellular Retinol-binding protein allows specific interaction of retinol with the nucleus in vitro. Proc. Natl. Acad. Sci. U. S. A. 76: 2204-2208.

30. Sani, B. P., and M. K. Donovan. 1979. Localization of retinoic acid-binding protein in nuclei and the nuclear uptake of retinoic acid. Cancer Res. 39: 2492-2496.

31. Shiu, R. P. C. 1979. Prolactin binding and processing by human breast cancer cells in long term tissue culture. Meeting of the Endocrine Society, Anaheim, Calif. Abstract 820

32. Osborne, C. K., B. Hamilton, G. Titus, and R. B. Livingston. 1979. Epidermal growth factor stimulates growth of human breast cancer cells. Meeting of the Endocrine Society, Anaheim, Calif. Abstract 324.

33. Allegra, J. C., and M. E. Lippman. 1979. Growth of a human breast cancer cell line in serum free hormone supplemented medium. Cancer Res. 38: 3823-3829. 